\title{
AGE, GROWTH AND OTOLITH BIOMETRY-BODY LENGTH RELATIONSHIPS OF RED BANDFISH (Cepola macrophthalma L., 1758) IN THE SEA OF MARMARA, TURKEY
}

\author{
Ali İŞMEN ${ }^{1}$, Mukadder ARSLAN İHSANOĞLU ${ }^{1 *}$, İsmail Burak DABAN ${ }^{1}$, Haşim İNCEOĞLU² \\ ${ }^{1}$ Çanakkale Onsekiz Mart University, Marine Science and Technology Faculty, Fisheries and Fish Processing \\ Department, 17100, Çanakkale, TURKEY \\ ${ }^{2}$ Republic of Turkey Ministry of Agriculture and Forestry, Sheep Research Institute, Fisheries Deparment, 10200, \\ Bandırma, Balıkesir, TURKEY
}

Cite this article as:

İşmen A., Arslan İhsanoğlu M., Daban İ.B. \& İnceoğlu H. 2020. Age, Growth and Otolith Biometry-Body Length Relationships of Red Bandfish (Cepola macrophthalma L., 1758) in the Sea of Marmara, Turkey. Trakya Univ J Nat Sci, 21(2): 107-113, DOI: 10.23902/trkjnat.714201

Edited by:

Herdem Aslan

*Corresponding Author:

Mukadder Arslan İhsanoğlu

mukadderarslan@gmail.com

\section{ORCID ID:}

orcid.org/0000-0003-0072-5848

Key words:

Red bandfish

The Sea of Marmara

Length-weight

Growth

Age

\begin{abstract}
The age, growth, and the otolith biometry-total length relationships of Cepola macrophthalma (Linnaeus, 1758) were investigated. The individuals were caught with beam trawl in the Sea of Marmara from March 2012 to June 2014. The individual with $51.5 \mathrm{~cm}$ total length sampled in this study was recorded as the new maximum size of C. macrophthalma in the Marmara Sea. The length-weight relationship showed negative allometric growth with a $1.36 \mathrm{~b}$ value. Otolith length-otolith weight, otolith width-otolith weight, otolith length-total length, otolith width-total length, otolith length-otolith width and total length-otolith weight relationships were found as $\mathrm{OW}=0.0002 * \mathrm{OL}^{2.6377} \quad\left(\mathrm{R}^{2}=0.91\right), \quad \mathrm{OW}=0.001 * \mathrm{OWi}^{2.6215} \quad\left(\mathrm{R}^{2}=0.94\right), \quad \mathrm{O}=0.057 * \mathrm{TL}+3.2087$ $\left(\mathrm{R}^{2}=0.57\right), \quad \mathrm{OWi}=0.0316 * \mathrm{TL}+1.8511 \quad\left(\mathrm{R}^{2}=0.55\right), \quad \mathrm{OWi}=0.527 * \mathrm{OL}+0.2015 \quad\left(\mathrm{R}^{2}=0.86\right)$, $\mathrm{OW}=0.0004 * \mathrm{TL}+0.0029\left(\mathrm{R}^{2}=0.58\right)$, respectively. Ages were estimated from 80 otolith readings and the minimum and maximum ages observed were 1 and 5 years, respectively. The growth parameters of the von Bertalanffy equation were calculated as $\mathrm{L}_{\infty}=61.95 \mathrm{~cm}, \mathrm{~K}=0.19$ year ${ }^{-1}, \mathrm{t}_{0}=-$ 0.05 years. A great majority of the stock (77\%) consisted of younger individuals (1-2 age groups). Cepola macrophthalma stock consisted of mainly younger individuals which may indicate that an effective fishing pressure is effective on the stock.
\end{abstract}

Özet: Cepola macrophthalma (Linnaeus, 1758)'in yaş, büyüme ve otolit biyometri-total boy ilişkileri araştırılmıştır. Bireyler Mart 2012-Haziran 2014 tarihleri arasında Marmara Denizi'nde algarna ile yakalanmıştır. Bu çalışmada örneklenen 51,5 cm'lik $C$. macrophthalma bireyinin boyu, Marmara Denizi'nde bu tür için maksimum olarak kaydedilmiştir. Boy-ağırlık ilişkisi denklemine göre büyüme tipi negatif allometrik olarak belirlenmiştir $(b=1,36)$. Otolith boyu-otolith ağırlığı, otolith genişliği- otolith ağırlığı, otolith boyu-total boy, otolith genişliği-total boy, otolit boyu-otolit genişliğ $\mathrm{i}$, total boy-otolit ağırlığ ilişkileri $\mathrm{OW}=0,0002 * \mathrm{OL}^{2,6377}\left(\mathrm{R}^{2}=0,91\right), \mathrm{OW}=0,001 * \mathrm{OWi}^{2,6215}$ $\left(\mathrm{R}^{2}=0,94\right), \quad \mathrm{OL}=0,057 * \mathrm{TL}+3,2087 \quad\left(\mathrm{R}^{2}=0,57\right), \quad \mathrm{OWi}=0,0316 * \mathrm{TL}+1,8511 \quad\left(\mathrm{R}^{2}=0,55\right)$, $\mathrm{OWi}=0,527 * \mathrm{OL}+0,2015\left(\mathrm{R}^{2}=0,86\right) \quad \mathrm{OW}=0,0004 * \mathrm{TL}+0,0029 \quad\left(\mathrm{R}^{2}=0,58\right)$ olarak hesaplanmıştır. Yaşlar 80 adet otolit okumasından hesaplanmıştır; gözlemlenen en küçük ve en büyük yaşlar sırasılyla 1 ve 5 'tir. von Bertalanffy denklemine göre hesaplanan büyüme parametreleri değerleri $\mathrm{L} \infty=61,95 \mathrm{~cm}, \mathrm{~K}=0,19 \mathrm{yll}^{-1}, \mathrm{t}_{0}=-0,05$ y1l olarak belirlenmiştir. Stoğun büyük çoğunluğu (\%77) genç bireylerden (1-2 yaş grubu) oluşmaktadır. Marmara Denizi'nde C. macrophthalma stoğunun daha çok genç bireylerden oluşması stokların av baskısı altında olduğunu düşündürmektedir.

\section{Introduction}

The red bandfish, Cepola macrophthalma (Linnaeus, 1758) is a marine demersal fish species that inhabit soft and muddy bottoms at depths ranging from 15 to $400 \mathrm{~m}$ (Sanches 1991). It usually lives in vertical burrows and distributes singly or in groups. There is little information about early life stages of the species except that the eggs are pelagic. The main food source of the species are small crustaceans and chaetognaths (Whitehead et al. 1986). The maximum size of the species has been recorded as 80 $\mathrm{cm}$ TL in the Biscay Bay (Sanchez et al. 1995) but the mean length is at about $40 \mathrm{~cm}$ in Guiné-Bissau costs in the Atlantic Ocean (Sanches 1991). The details of ecology and life history of $C$. macrophthalma is poorly known. Although it is known as an eastern Atlantic origin species, 
it has an extensive geographical distribution from the Strait of Gibraltar to northern Senegal; northward extending into the Canary Islands, the Mediterranean and north Atlantic up to Scotland and the Orkney Islands (Smith-Vaniz 2015).

In the Mediterranean, $C$. macrophthalma is present in the Catalan Sea (Coll et al. 2006), the Gulf of Lions (Gaertner et al. 1998), the Ligurian Sea (Molinari \& Tunesi 2003), the Tyrrhenian Sea (Colloca et al. 2004, Carpentieri et al. 2005), the Cretan Sea (Kallianiotis et al. 2000), the Aegean Sea (Stergiou 1999, Lamprakis et al. 2003, Machias et al.2004, Labropoulou \& Papaconstantinou 2005, Gokce \& Metin 2007, Özaydin $e t$ al. 2007) and the Sea of Marmara (Bok et al. 2011). It also is present in the Levantine Sea and along the North African coast. It does not occur in the Black Sea (SmithVaniz 2015). Due to the minor commercial interest and threats, C. macrophthalma is listed as Least Concern in the IUCN Red List of Threatened Species (IUCN 2015, Smith-Vaniz 2015).

The majority of the literature on the biology and ecology of the species is about its feeding, age, growth, reproduction, and length weight relationships (LWRs) (Stergiou et al. 1992, Kaya et al. 2001, Vallisneri et al. 2006, Dulčić et al. 2008, Özaydın et al. 2007, Bok et al. 2011). Some studies investigated the age, growth, and length-weight relationship parameters in Turkey seas (Kaya et al. 2001, Özaydin et al. 2007, Leblebici 2007, Bok et al. 2011) of which one study reported data on length-weight relationship parameters in the Sea of Marmara (Bok et al. 2011).

The aim of this study is to estimate the relationship between otolith size and fish size, age and growth parameters of $C$. macrophthalma in the Sea of Marmara. We reported the first results on the age and growth of $C$. macrophthalma in the Sea of Marmara and the first results about otolith and fish morphometric relationships in general.

\section{Materials and Methods}

A total of 105 C. macrophthalma specimens were sampled in the Sea of Marmara with monthly samplings between March 2012 and June 2014 from, (Fig. 1). The samplings were carried out using a commercial beam trawl net. Total length (TL) and weight (W) values of the samples were determined to the nearest $1 \mathrm{~mm}$ and $0.01 \mathrm{~g}$, respectively. The length-weight relationship was determined according to the formula of Le Cren (1951): $\mathrm{W}=\mathrm{a} * \mathrm{~L}^{\mathrm{b}}$, where $\mathrm{W}$ is the total body weight $(\mathrm{g}), \mathrm{L}$ is the total length $(\mathrm{cm})$ while $a$ and $b$ are constants. To check whether fish growth is statistically different from isometric growth $(b=3)$ Student's t-test was used by the equation according to Sokal \& Rohlf (1987): ts=(b$3) / \mathrm{SE}(\mathrm{b})$, where ts is the t-test value, $\mathrm{b}$ is the slope and $\mathrm{SE}(\mathrm{b})$ is the standard error of the $b$ value.

The ages of 80 specimens were determined using the sagittal otoliths, while the rest 25 otoliths were not evaluated as they were broken to a degree which made it impossible to determine their age. The otolith is the most commonly used material for age estimation (Holden \& Raitt 1974) and was commonly used for age determination of C. macrphthalma (Kaya et al. 2001, Leblebici 2007). The otolith of this species is easly readible. The nucleus is totally opaque, first translucent band starts after the opaque zone. Estimation of age was based almost exclusively on the interpretation of otolith structures for the presence of translucent and opaque zones which are assumed to represent winter and summer growth periods and the date of birth is assumed 1 January. Sagittal otoliths from each fish were removed and cleaned. The size of the otoliths was measured with QCapture Digital Imaging Software attached on an Olympus SZX-7 stereomicroscope with a camera sensitivity to $0.01 \mathrm{~mm}$ and weighed with the precision of $0.0001 \mathrm{~g}$ by scales (Fig. 2). Annual rings on the whole otoliths were counted in glycerin under a stereomicroscope. The translucent and opaque zones were counted for age determination. The otoliths were read by three different observers and age was determined when minimum two of the readings agreed.

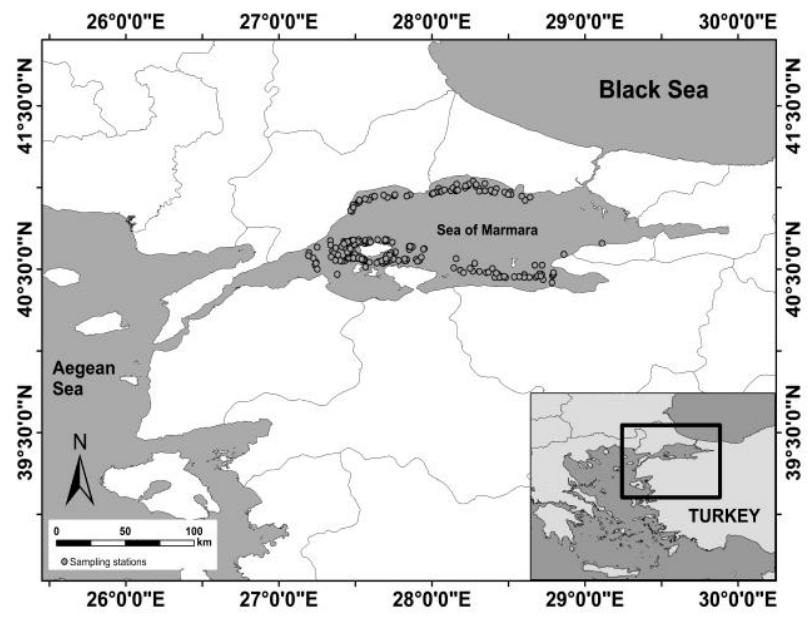

Fig. 1. Sampling stations in the Sea of Marmara, Turkey (İşmen et al. 2018). Each open dot represent a different station.

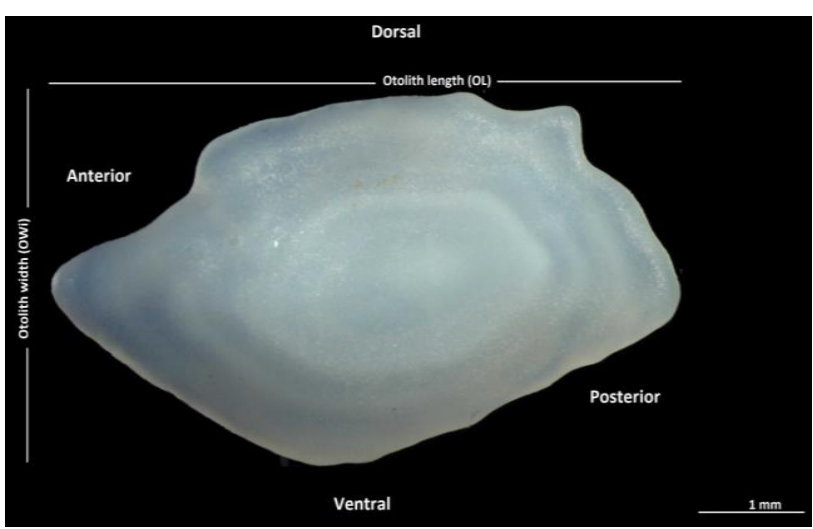

Fig. 2. Distal view and measurement axes of the sagittal otolith of C. macrophthalma in the Sea of Marmara (TL: $31.8 \mathrm{~cm}, \mathrm{~W}$ : $18.56 \mathrm{~g}$, Age: 3). 
Otolith length (OL), otolith width (OWi) and otolith weight $(\mathrm{OW})$ were measured in all otoliths as shape parameters. For the analysis of relationships between OLOW, OWi-OW, OL-TL, OWi-L, OL-OWi and TL-W, the equation $\mathrm{y}=\mathrm{ax}+\mathrm{b}$ was used where $\mathrm{y}$ is $\mathrm{OW}$, OWi or OL, $\mathrm{x}$ is TL or OL, and equation $y=\mathrm{ax}^{\mathrm{b}}$ where $\mathrm{y}$ is $\mathrm{OW}, \mathrm{x}$ is $\mathrm{OL}$ or OWi, and a and b are constant coefficients. The chosen regression model was decided based on the magnitude of the $\mathrm{R}^{2}$ value.

Growth parameters were determined using the von Bertalanffy equation (Beverton \& Holt 1957): $\mathrm{Lt}=\mathrm{L}_{\infty}$ (1$\left.\mathrm{e}^{-\mathrm{K}(\mathrm{t}-\mathrm{t}} 0_{0}\right)$, where $\mathrm{L}_{\infty}$ is the asymptotic total length, $\mathrm{L}_{\mathrm{t}}$ the total length at age $t, K$ the growth curvature parameter and $t_{0}$ is the theoretical age when fish would have been at zero total length. Growth parameters were estimated using the "Analyze of length at age data" method in FAO-ICLARM Stok Assessment Tools (FISAT II) software. For the sake of comparison, the index of overall growth performance $\Phi$ proposed by Pauly \& Munro (1984) was calculated. This test indicated the reliability of age estimates since it had been suggested that phi-prime test values were similar for the same species and genera. The test was based on $\Phi$ $=\log \mathrm{K}+2 * \log \mathrm{L}_{\infty}($ Pineiro \& Sainza 2003).

All statistics were analyzed using the MINITAB 16 program. The normality assumptions were checked with Kolmogorov-Simirnov test. Student's t-test was used for analyzing the fish growth type. Paired t-test was used to test whether there is a difference between right and left otoliths. The regression models were used to explain relationships between fish and otolith morphometry.

\section{Results}

A total of 105 specimens ranged from 8.5 to $51.5 \mathrm{~cm}$ in TL and from 1.65 to $24.54 \mathrm{~g}$ in weight. A pair of 80 sagittal otoliths were measured. Otolith length, weight and width measurements are given in Table 1. There was no significant difference between right and left otoliths (paired t-test, $\mathrm{P}=0.63$ ), therefore, only right otoliths $(\mathrm{n}=80)$ were used for further analysis.

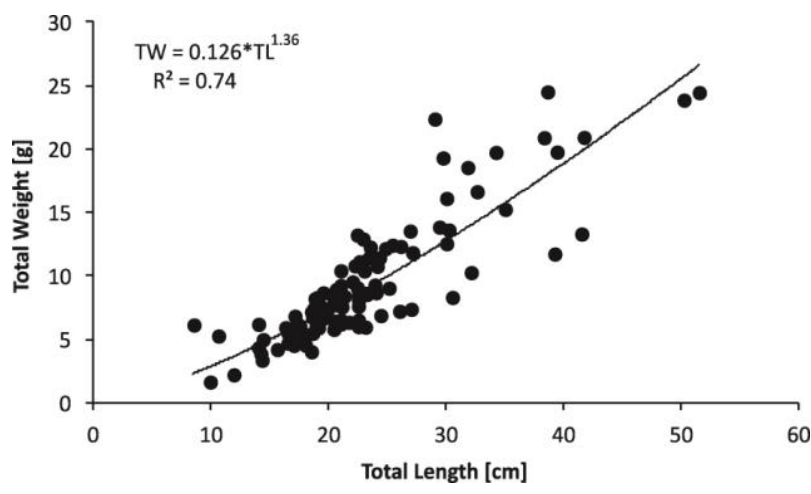

Fig. 3. Length - weight relationship of C. macrophthalma in the Sea of Marmara.

Length-weight relationship was calculated as $\mathrm{W}=0.126 * \mathrm{TL}^{1.36}\left(\mathrm{R}^{2}=0.74\right)$ and showed a negative allometric growth pattern (Fig. 3). Otolith length-otolith weight, otolith width-otolith weight, otolith length-total length, otolith width-total length, otolith length-otolith width and total length-otolith weight relationships were found as $\mathrm{OW}=0.0002 * \mathrm{OL}^{2.6377}\left(\mathrm{R}^{2}=0.91, \mathrm{p}<0.001\right)$, $\mathrm{OW}=0.001 * \mathrm{OWi}^{2.6215} \quad\left(\mathrm{R}^{2}=0.94, \quad \mathrm{p}<0.001\right)$, $\mathrm{OL}=0.057 * \mathrm{TL}+3.2087 \quad\left(\mathrm{R}^{2}=0.57, \quad \mathrm{p}<0.001\right)$, $\mathrm{OWi}=0.0316 * \mathrm{TL}+1.8511 \quad\left(\mathrm{R}^{2}=0.55, \quad \mathrm{p}<0.001\right)$, $\mathrm{OWi}=0.527 * \mathrm{OL}+0.2015 \quad\left(\mathrm{R}^{2}=0.86, \quad \mathrm{p}<0.001\right)$, $\mathrm{OW}=0.0004 * \mathrm{TL}+0.0029 \quad\left(\mathrm{R}^{2}=0.58, \quad \mathrm{p}<0.001\right)$, respectively (Fig. 4).

The von Bertalanffy growth parameters for $C$. macrophthalma were estimated as $\mathrm{L}_{\infty}=61.95 \mathrm{~cm}, \mathrm{~K}=0.19$ year $^{-1}, \mathrm{t}_{0}=-0.5$ year and growth performance index was calculated as $\Phi=2.86$ (Fig. 5).

The age interval ranged between 1 and 5 . The highest represented age group was $2(46 \%)$ and the age group 1 $(30 \%)$ and age group 3 were considerably well represented (Table 2).

Table 1. Morphometric measurements of sampled C. macrophthalma and their and otolith length, weight and width.

\begin{tabular}{ccccccccc}
\hline \hline & \multirow{2}{*}{ TL $(\mathbf{c m})$} & \multirow{2}{*}{ W $(\mathbf{g})$} & \multicolumn{2}{c}{ OL $(\mathbf{m m})$} & \multicolumn{2}{c}{ OWi $(\mathbf{m m})$} & \multicolumn{2}{c}{ OW $(\mathbf{g})$} \\
\cline { 4 - 8 } & & $\mathbf{R}$ & $\mathbf{L}$ & $\mathbf{R}$ & $\mathbf{L}$ & $\mathbf{R}$ & $\mathbf{L}$ \\
\hline \hline Min. Max. & $8.5-51.5$ & $1.65-24.52$ & $3.35-6.1$ & $3.23-6.2$ & $1.86-3.8$ & $1.85-3.29$ & $0.0051-0.0245$ & $0.0053-0.0254$ \\
Mean & $22.96 \pm 0.75$ & $9.38 \pm 0.48$ & $4.50 \pm 0.06$ & $4.49 \pm 0.0$ & $2.58 \pm 0.0$ & $2.58 \pm 0.03$ & $0.013 \pm 0.0004$ & $0.012 \pm 0.0004$ \\
$\mathbf{N}$ & 105 & 105 & 80 & 80 & 80 & 80 & 80 & 80 \\
\hline \hline
\end{tabular}

TL: total length, W: weight, OL: otolith length, OWi: otolith width, OW: otolith weight, R: right, L: left

Table 2. The age-length key of C. macrophthalma.

\begin{tabular}{cccc}
\hline \hline & & \multicolumn{2}{c}{ Total length (cm) } \\
\cline { 3 - 4 } Age & $\mathbf{N}$ & Min-Max & Mean \\
& & $14.0-19.9$ & $22.0 \pm 1.6$ \\
2 & 23 & $18.0-26.9$ & $29.4 \pm 2.7$ \\
3 & 37 & $25.1-34.2$ & $35.5 \pm 3.9$ \\
4 & 12 & $30.0-39.2$ & $50.9 \pm 0.9$ \\
\hline \hline
\end{tabular}


(a)

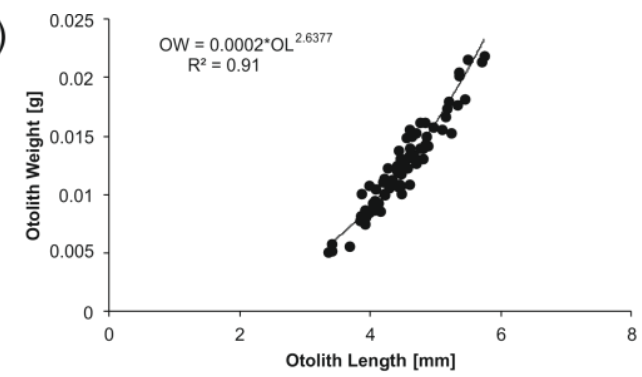

(b)

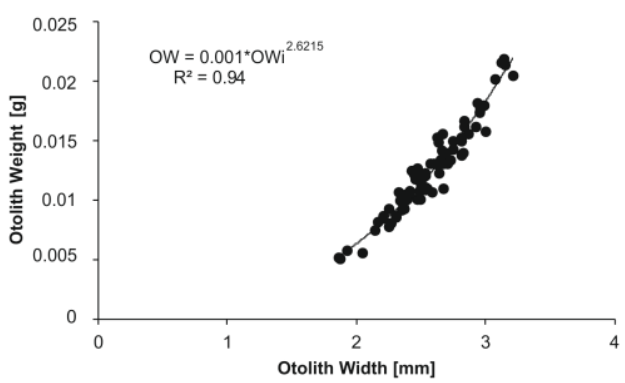

(c)

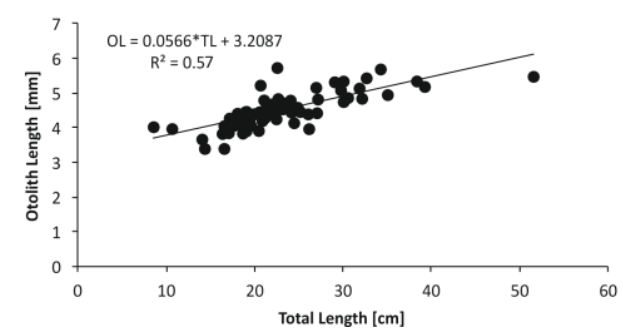

(d)

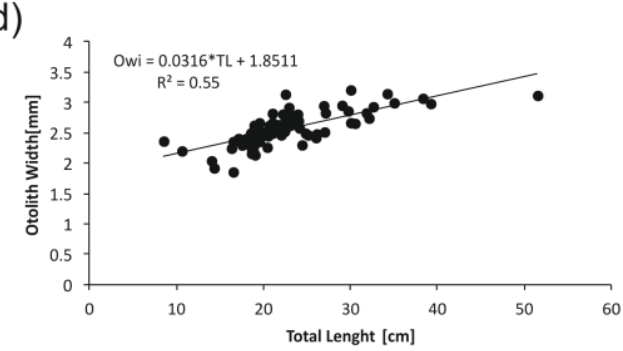

(e)

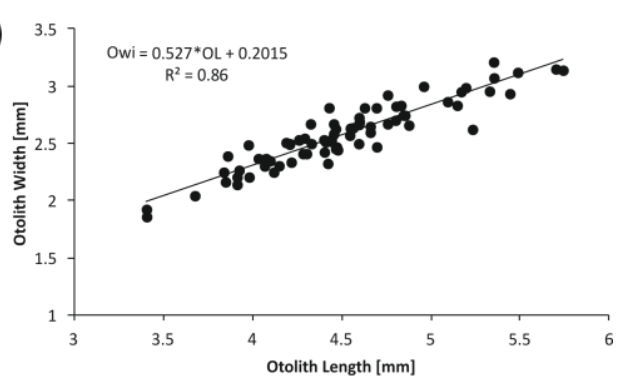

(f)

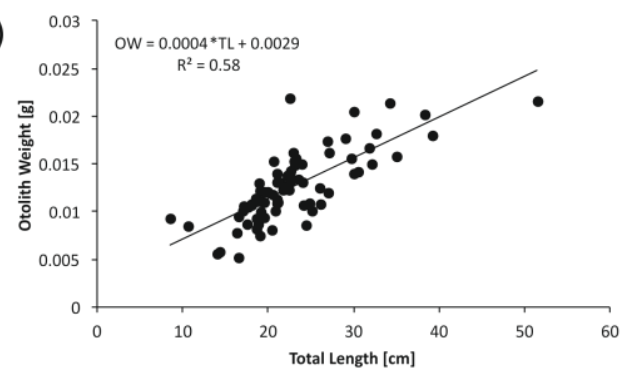

Fig. 4. OL-OW (a), OW-OWi (b), TL-OL (c), TL-OWi (d), OL-OWi (e) and TL-OW (f) relationships of C. macrophthalma in the Sea of Marmara.

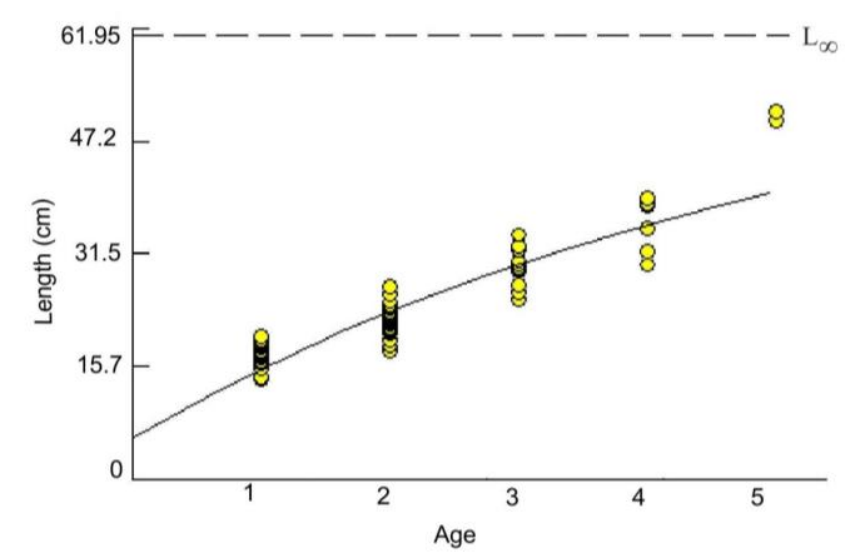

Fig. 5. The von Bertalanffy growth curve of C. macrophthalma in the Sea of Marmara.

\section{Discussion}

The life span of the C. macropthalma is shorter than many demersal fish species (Dulčić et al. 2008). According to our results, the oldest individual was 5 years old. A great number of limiting factors may have contributed to the occurrence of a shorter life span, as high fishing pressure, nutritional inadequacy, morphological characteristics of the species, etc. The same results were observed in studies conducted in the eastern Adriatic (Dulčić et al. 2008), Adriatic (Vallisneri et al. 2006),
Izmir Bay (Kaya et al. 2001) and Euboikos Gulf, western Aegean Sea (Stergiou \& Papaconstantinou 1993). In contrast, relatively long life spans were determined in studies conducted in the British Isles (Atkinson 1976) and in Pagassitikos Gulf, western Aegean Sea (Stergiou \& Papaconstantinou 1993). This may be a result of lower fishing pressure and availability of more sheltering areas for C. macropthalma in these areas. Its elongated, laterally compressed body shape [horizontal dimension 16 times the vertical one, Stergiou \& Papaconstantinou 
(1993)] may be advantageous for escaping from the mesh of fishing nets. Barely squeeze in the trawl and beam trawl bag prevents occurring of this advantage. It's slow, wavy mode of swimming (Wilson 1953) may make the species an open target for fishing vessels. The observed short life span in a great majority of studies caused us to focus on fishing pressure. Trawl fishing is the main reason for fishing pressure on demersal species. Demersal trawling is prohibited in the Sea of Marmara. Conversely, beam trawl fishery is legally allowed and extensively applied. The relatively lower growth rate and shorter life span may have resulted from the high fishing pressure of beam trawl fishery in the Marmara Sea. The age-frequency distribution also supports this finding. A majority of individuals were of age groups 1 and 2 .

The $b$ value shows negative allometry (Student t-test). Negative allometry is mandatory due to the physical nature of the species. The exponent $b$ usually varies between 2.5-3.5 for other fish species. Merely, the lifestyle of $C$. macrophthalma may cause unproportional length increases according to growth in weight, and this may induce lower $b$ values (Froese 2006). However, the calculated $b$ value (1.358) in this study reveals the lowest value compared with the others (Table 3 ). Poor food availability and competition for food resources in the Sea of Marmara may have caused this situation. In a single study conducted in the Sea of Marmara on $C$. macrophthalma, Bok et al. (2011) calculated the $b$ value as 1.510 .

Due to the absence of studies on the age and growth parameters of C. macropthalma in the Sea of Marmara, growth parameters were compared with other studies conducted in adjacent waters. In almost all studies, the calculated $\mathrm{L}_{\infty}$ and $\mathrm{K}$ values are greater than the ones in this study. The estimated $\mathrm{L}_{\infty}$ and $\mathrm{K}$ values in our study are in agreement with the findings of Stergiou et al. (1992). Also, the same $\mathrm{K}$ value was obtained in the findings of Kaya et al. (2001), whereas our calculated $\mathrm{L}_{\infty}$ value is lower. We think this may be due to the high number of smaller individuals in our data set (Table 4).

Table 3. Total length-total weight relationships of C. macrophthalma obtained by different researchers.

\begin{tabular}{|c|c|c|c|c|c|c|c|}
\hline Researcher(s) & Region & $\mathbf{N}$ & Sex & $\overline{\mathbf{a}}$ & $\overline{\mathbf{b}}$ & $\overline{\mathbf{R}^{2}}$ & Length \\
\hline \multirow{3}{*}{ Stergiou 1991} & \multirow{3}{*}{$\begin{array}{l}\text { Euboikos and } \\
\text { Pagassitikos Gulfs }\end{array}$} & 515 & Female & 0.0491 & 1.667 & 0.75 & \multirow{3}{*}{$11.8-51.3$} \\
\hline & & 452 & Male & 0.0401 & 1.716 & 0.75 & \\
\hline & & 967 & Mixed & 0.0456 & 1.683 & 0.75 & \\
\hline Pereda \& Villamor 1991 & Cantabrica & 103 & Mixed & 0.0128 & 2.169 & 0.98 & $11-65$ \\
\hline Stergiou et al. 1992 & Aegean Sea & 3351 & Mixed & 0.0166 & 2.03 & 0.93 & $10.4-58.7$ \\
\hline \multirow{2}{*}{ Kaya et al. 2001} & \multirow{2}{*}{ Aegean Sea } & 131 & Female & 0.3288 & 1.270 & 0.79 & $11.5-45.6$ \\
\hline & & 144 & Male & 0.2154 & 1.384 & 0.81 & $19.8-47.1$ \\
\hline Lamprakis et al. 2003 & North Aegean Sea & 1021 & Mixed & 0.0863 & 1.543 & 0.80 & $10.3-53.2$ \\
\hline Özaydın \& Taşkavak 2006 & İzmir Bay & 254 & & 0.0203 & 1.97 & 0.98 & \\
\hline Özaydın et al. 2007 & İzmir Bay & 881 & Mixed & 0.0741 & 1.669 & 0.95 & $16.2-50.9$ \\
\hline \multirow{2}{*}{ Leblebici 2007} & \multirow{2}{*}{ İzmir Bay } & 340 & Female & 0.0189 & 2.063 & 0.91 & $17.4-39.6$ \\
\hline & & 1450 & Male & 0.0405 & 1.823 & 0.94 & $16.3-54.0$ \\
\hline Türker Çakır et al. 2007 & Edremit Bay & 356 & Mixed & 0.1379 & 1.4421 & 0.88 & $12.3-43.7$ \\
\hline İşmen et al. 2007 & Saros Bay & 136 & Mixed & 0.03461 & 1.8533 & 0.92 & $19.1-49.6$ \\
\hline İlkyaz et al. 2008 & Aegean Sea & 635 & Mixed & 0.0716 & 1.65 & 0.97 & $16.4-51.6$ \\
\hline Bok et al. 2011 & Northern Sea of Marmara & 17 & Mixed & 0.0093 & 1.510 & 0.84 & $20.8-46.7$ \\
\hline Torres et al. 2012 & Gulf of Cadiz & 447 & Mixed & 0.0270 & 2.009 & 0.95 & $6.8-98.2$ \\
\hline Bilge et al. 2014 & Aegean Sea & 988 & Mixed & 0.0126 & 1.4421 & 0.88 & $7.5-51$ \\
\hline This study & Sea of Marmara & 105 & Mixed & 0.126 & 1.358 & 0.74 & $8.5-51.5$ \\
\hline
\end{tabular}

Table 4. Parameters of von Bertalanffy growth equation $\left(\mathrm{K}, \mathrm{L}_{\infty}, \mathrm{t}_{0}, \Phi\right)$ obtained by different researchers.

\begin{tabular}{|c|c|c|c|c|c|c|c|}
\hline Researcher(s) & Region & $\overline{\mathbf{N}}$ & 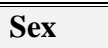 & $2 \infty$ & $\overline{\mathrm{K}}$ & t0 & $\overline{\bar{\Phi}}$ \\
\hline Stergiou et al. 1992 & South Evvoikos Gulf & & & 42.5 & 0.379 & $\begin{array}{l}-0.1 \\
\end{array}$ & 2.84 \\
\hline Stergiou et al. 1992 & $\begin{array}{l}\text { North Evvoikos and } \\
\text { Pagassitikos Gulfs }\end{array}$ & & & 67.6 & 0.214 & 0 & 2.99 \\
\hline Kaya et al. 2001 & İzmir Bay & & Female & $\begin{array}{l}78.5 \\
832\end{array}$ & $\begin{array}{l}0.17 \\
0.16\end{array}$ & $\begin{array}{r}0.1 \\
0.09\end{array}$ & $\begin{array}{l}3.02 \\
3.04\end{array}$ \\
\hline Leblebici 2007 & İzmir Bay & $\begin{array}{l}44 \\
141\end{array}$ & $\begin{array}{l}\text { Female } \\
\text { Male }\end{array}$ & $\begin{array}{l}48.78 \\
56.82\end{array}$ & $\begin{array}{l}0.354 \\
0.393\end{array}$ & $\begin{array}{l}-0.39 \\
-0.45\end{array}$ & \\
\hline This study & Sea of Marmara & 80 & Mixed & 61.95 & 0.19 & -0.50 & 2.86 \\
\hline
\end{tabular}


Since otolith biometry (shape, size, etc.) varies according to to size of the fish species, the relationship between otolith biometry and fish length can be useful for species identification and prey length from the otoliths found in stomach content (Campana \& Thorrold 2001). Besides, it can be used by archaeologists to reveal the mystery from excavation (Hajkova et al. 2003). Otolith biometry fish length relationship has been carried out for many species (Appelbaum \& Hechte 1978, Hare \& Cowen 1995, Hoşsucu et al. 1999, Bostanc1 2009, Park et al. 2018). This study reveals the first results for otolith biometry-total length relationship approach of $C$. macrophthalma. The morphological difference was not found between the left and right otoliths (paired t-test, $\mathrm{p}=0.63$ ). Therefore the researchers studying on $C$. macrophthalma can use both otoliths in their calculations.

Because of its minor commercial interest, $C$. macrophthalma is listed as Least Concern in the IUCN Red List of Threatened Species (IUCN 2015). According to

\section{References}

1. Appelbaum, S. \& Hechte, T. 1978. Otolith length/fish length relationship of leptocephali, elvers, and sub-adult (reared) eels Anguilla anguilla. Environmental Biology of Fishes, 3(2): 245-247.

2. Atkinson, R.G.A. 1976. Some preliminary field observations of the burrows of the red band- fish, Cepola rubescens. Journal of Fish Biology, 9: 181-183.

3. Beverton, R.J.H. \& Holt, S.J. 1957. On the dynamics of exploited fish populations. H. M. Stationary Off, London, $533 \mathrm{pp}$.

4. Bilge, G., Yapıc1, S., Filiz, H. \& Cerim, H. 2014. Weightlength relations for 103 fish species from the southern Aegean Sea, Turkey. Acta Ichthyologica et Piscatoria, 44(3): 263-269.

5. Bok, T.D., Gokturk, S.D., Kahraman, A.E., Alicli, T.Z., Acun, T. \& Ates, C. 2011. Length-weight relationships of 34 fish species from the Sea of Marmara, Turkey. Journal of Animal and Veterinary Advance, 10(23): 3037-3042.

6. Bostanc1, D. 2009. Otolith biometry-body length relationships in four fish species (chub, pikeperch, crucian carp, and common carp). Journal of Freshwater Ecology, 24: 619-624.

7. Campana, S.E. \& Thorrold, S.R. 2001. Otoliths, increments, and elements: keys to a comprehensive understanding of fish populations? Canadian Journal of Fisheries and Aquatic Sciences, 58: 30-38.

8. Carpentieri, P., Colloca, F. \& Ardizzone, G.D. 2005. Daynight variations in the demersal nekton assemblage on the Mediterranean shelf break. Estuarine and Coastal Shelf Science, 63: 577-588.

9. Coll, M., Palomera, I., Tudela, S. \& Sardà, F. 2006. Trophic flows, ecosystem structure and impacts in the South Catalan Sea, Northwestern Mediterranean. Journal of Marine Systems, 59: 63-96.

10. Colloca, F., Carpentieri, P., Balestri, E. \& Ardizzone, G.D. 2004. A critical habitat for Mediterranean fish resources:
IUCN, the species has been assessed lastly in 2013 and its population trend is identified as unknown. In addition, the stocks of mature individuals are stated to show a decline trend. Cepola macrophthalma is occasionally fished for utilizing fresh, fish soup, fish oil or fishmeal (Whitehead et al. 1986) especially around Spain, Portugal and along the West African coasts. Although it has no commercial value, it is known to have a high discard rate in trawling fishery in the Aegean and the Mediterranean Sea and the Sea of Marmara in Turkey. Knowledge of specific conservation measures for $C$. macrophthalma is unknown, and there exists not enough scientific work to take protective measures in the Sea of Marmara. More detailed further studies should be advised especially on the biology and population dynamics.

\section{Acknowledgement}

This study was supported by the General Directorate of Agricultural Research and Policy of Turkey with the project number TAGEM/HAYSUD/2011/09/02/04.

shelf-break areas with Leptometra phalangium (Echinodermata: Crinoidea). Marine Biology, 145: 11291142.

11. Dulčić, J., Kokan, B., Vrgoč, N., Glamuzina, B., Conides, A.J. \& Skaramuca, B. 2008. Age, growth and mortality of red bandfish, Cepola macrophthalma (L.), in the eastern Adriatic Sea (Croatian coast). Journal of Applied Ichthyology, 24: 351-353.

12. Froese, R. 2006. Cube law, condition factor and weightlength relationships: history, meta analysis and recommendations. Journal of Applied Ichthyology, 22: 241-253.

13. Gaertner, J.C., Chessel, D. \& Bertrand, J. 1998. Stability of spatial structures of demersal assemblages: a multitable approach. Aquatic Living Resources, 11(2): 75-85.

14. Gokce, G. \& Metin, C. 2007. Landed and discarded catches from commercial prawn trammel net fishery. Journal of Applied Ichthyology, 23: 543-546.

15. Hajkova, P., Roche, K. \& Kocian, L. 2003. On the use of diagnostic bones of brown trout, Salmo trutta m. fario, grayling, Thymallus thymallus and Carpathian sculpin, Cottus poecilopus in Eurasian otter, Lutra lutra diet analysis. Folia Zoologia, 52(4): 389-398.

16. Hare, J.A. \& Cowen, R.K. 1995. Effect of age, growth rate, and ontogeny on the otolith size-fish size relationship in bluefish, Pomatomus saltatrix, and the implications for backcalculation of size in fish early life history stages. Canadian Journal of Aquatic Sciences, 52: 1909-1922.

17. Holden, M.J. \& Raitt, D.F.S. 1974. Manual of fisheries science part 2-methods of resource investigation and their application. Food and Agriculture Organization of the United Nations, Rome, 214 pp.

18. Hoşsucu, B., Kaya, M. \& Taşkavak, E. 1999. An investigation of growth parameters and otolit-total length relationship of Solea solea (L., 1758) (Pisces: Soleidae) in İzmir Bay. Israel Journal of Zoology, 45: 277-287. 
19. IUCN, 2015. The IUCN red list of threatened species. http://www.iucnredlist.org (Date accessed: 10.02.2020).

20. İlkyaz, A.T., Metin, G., Soykan, O. \& Kinacigil, H.T. 2008. Length-weight relationship of 62 fish species from the Central Aegean Sea, Turkey. Journal of Applied Ichthyology, 24: 699-702.

21. İşmen, A., Arslan İhsanoğlu, M. \& İnceoğlu, H. 2018. Length-Weight Relationships of three Fish Species in the Sea of Marmara, Turkey. Thalassas, 2: 373-376.

22. İşmen, A., Özen, Ö., Altinağaç, U., Özekinci, U. \& Ayaz, A. 2007. Weight-Length Relationships of 63 Fish Species in Saros Bay, Turkey. Journal of Applied Ichthyology, 23: 707-708.

23. Kallianiotis, A., Sophronidis, K., Vidoris, P. \& Tselepides, A. 2000. Demersal fish and megafaunal assemblages on the Cretan continental shelf and slope (NE Mediterranean): seasonal variation in species, density, biomass and diversity. Progress in Oceanography, 46: 429-255.

24. Kaya, M., Özaydin, O. \& Benli, H.A. 2001. Age and growth parameters of the red bandfish (Cepola rubescens L., 1766) in Izmir Bay. Turkish Journal of Zoology, 25: 111-116.

25. Labropoulou, M. \& Papaconstantinou, C. 2005. Effect of fishing on community structure of demersal fish assemblages. Belgium Journal of Zoology, 135(2): 191-197.

26. Lamprakis, M.K., Kallianiotis, A.A., Moutopoulos, D.K. \& Stergiou, K.I. 2003. Weight-length relationships of fishes discarded by trawlers in the North Aegean Sea. Acta Ichthyologica et Piscatoria, 33(2): 145-152.

27. Le Cren, E.D. 1951. The length weight relationship and seasonal cycle in gonad weight and condition in the Perch (Perca fuluviatilis). Journal of Animal Ecology, 20(2): 201219.

28. Leblebici, S. 2007. Investigation on the biological properties of Red Bandfish (Cepola macrophthalma Linnaeus, 1758) in İmir Bay. Ege University, Master Thesis, $89 \mathrm{p}$.

29. Machias, A., Karakassis, I., Labropoulou, M., Somarakis, S., Papadopoulou, K.N. \& Papaconstantinou, C. 2004. Changes in wild fish assemblages after the establishment of a fish farming zone in an oligotrophic marine ecosystem. Estuarine, Coastal and Shelf Science, 60(4): 771-779.

30. Molinari, A. \& Tunesi, L. 2003. Characterization of the artisanal fishery activities in the Bergeggi Island's waters (Ligurian Sea). Biologia Marina Mediterranea, 10(2): 706709.

31. Özaydin, O., Uckun, D., Akalin, S., Leblebici, S. \& Tosunoglu, Z. 2007. Length-weight relationships of fishes captured from Izmir Bay, central Aegean Sea. Journal of Applied Ichthyology, 23(6): 695-696.

32. Özaydın, O. \& Taskavak, E. 2006. Length-weight relationships for 47 fish species from Izmir Bay (eastern Aegean Sea, Turkey). Acta Adriatica, 47(2): 211-216.

33. Park, J.M., Gaston, T.F., Riedel, R. \& Williamson, J.E. 2018. Biometric relationships between body and otolith measurements in nine demersal fishes from north-eastern Tasmanian waters, Australia. Journal of Applied Ichthyology, 34: 801-805.
34. Pauly, D. \& Munro, J.L. 1984. Once more on the comparison of growth in fish and invertebrates, Fishbyte, 2(1): $1-21$.

35. Pereda, P. \& Villamor, B. 1991. Relaciones biometricas en peces de la plataforma Cantabrica. Madrid Ministerio de Agricultura, Pesca y Alimentación, Secretaría General Técnica, Spain, 39 pp.

36. Pineiro, C. \& Sainza, M. 2003. Age estimation, growth and maturity of the European hake, Merluccius merluccius (Linnaeus, 1758) from the Iberian Atlantic waters. ICES Journal of Marine Science, 60: 1086-1102.

37. 36. Sanches, J.G. 1991. Catálogo dos principais peixes marinhos da república de Guiné-Bissau. Instituto Nacional de Investigação das Pescas, Portugal, 429 pp.

38. Sanchez, F., de la Gandara, F. \& Gancedo, R. 1995. Atlas de los peces demersales de Galicia y el Cantábrico, Otoño 1991-1993. Instituto Español de Oceanografia, Madrid, Spain, 99 pp.

39. Smith-Vaniz, W.F. 2015. Cepola macrophthalma, the IUCN red list of threatened species 2015. (Date accessed: 10.02.2020)

40. Sokal, R.R. \& Rohlf, F.L. 1987. Introduction to biostatistics. W. H. Freeman and Co., New York, 363 pp.

41. Stergiou, K.I. 1991. Biology, ecology and dynamics of Cepola macrophthalma (L., 1758) (Pisces: Cepolidae) in the Euboikos and Pagassitikos Gulfs. Aristotle University, Ph.D. Thesis, Thessaloniki, Greece, 222 pp.

42. Stergiou, K.I. 1999. Intraspecific variations in size and age at maturity for red bandfish, Cepola macrophthalma. Environmental Biology of Fishes, 54: 151-160.

43. Stergiou, K.I., Economidis, P. \& Sinis A. 1992. Age, growth and mortality of red bandfish, Cepola macrophthalma (L.), in the western Aegean Sea (Greece). Journal of Fish Biology, 40 (3): 395-418.

44. Stergiou, K.I. \& Papaconstantinou, C. 1993. Natural mortality of red bandfish, (Cepola macrophthalma (L.), in the Aegean Sea (Greece): comparison of direct and indirect estimation methods. Fisheries research, 16: 347-361.

45. Torres, M.A., Ramos, F. \& Sobrino, I. 2012. Length-weight relationships of 76 fish species from the Gulf of Cadiz (SW Spain). Fisheries Research, 127-128: 171-175.

46. Türker Çakır, D., Torku Koç, H., Başusta, A. \& Başusta, N. 2007. LengthWeight Relationships of 24 Fish Species From Edremit Bay Aegean Sea. e-Journal of New World Sciences Academy Natural and Applied Sciences, 3(1): 4751.

47. Vallisneri, M., Piccinetti, C. \& Tommasini S. 2006. Age, growth, and gonad organization in red bandfish (Cepola macrophthalma L., 1758) from the Adriatic Sea. Acta Adriatica, 47 (2): 217-221.

48. Whitehead, P.J.P., Bauchot, M.L., Hureau, J.C., Nielsen, J. $\&$ Tortonese, E. 1986. Fishes of the North-Eastern Atlantic and the Mediterranean. United Nations, Educational, Scientific and Cultural Organization, Paris, 849 pp.

49. Wilson, D.P. 1953. Notes from the Plymouth aquarium. II. Journal of Marine Biological Association UK, 32: 199-208. 